\title{
Türkiye'deki Kullanıcı Deneyimi Profesyonellerinin Profili, Çalışma Ortamları, Kullandıkları Yöntemler ve Mevcut İş Akışı İçindeki Konumları
}

\author{
Yavuz iNAL \\ Kerem RIZVANOĞLU
}

yardımcı doçent doktor, atıım üniversitesi, mühendislik fakültesi, yavuz.inal@atilim.edu.tr

doçent doktor, galatasaray üniversitesi, iletişim fakültesi krizvanoglu@gsu.edu.tr

\section{Abstract}

The Profiles of the Turkish User Experience Professionals, Their Work Environment, The Methods They Use and Their Position in the Workflow

This study aims to present a detailed analysis on Turkish User Experience (UX) ecosystem by investigating the profiles of Turkish UX professionals; methods they use in their process and their position in the relevant workflow. A total of 91 UX professionals participated to the study. Due to the findings, most of the participants work in the largescale companies of the private sector located in istanbul. The interest of the small-scale companies towards UX is more when compared with mid-scale companies, however the public organizations revealed limited interest. The participants did not describe themselves as knowledgeable about UX. In order to support their self-improvement in their workplace, the participants want to enrich the communication channels and sources in the organization. The participants could not attend to the national and international activities on UX and they did not have any active communication with the national and international UX communities.

keywords: user experience professionals, user experience (ux), usability, human-computer interaction 


\section{Résumé}

\section{Les profils des professionnels turcs d'expérience utilisateur, leur environnement de travail, les méthodes qu'ils utilisent et leur position dans ce processus}

Cette étude a pour but de présenter une analyse détaillée de l'écosystème d'expérience utilisateur (UX) turque en étudiant les profils des professionnels d'UX turc; les méthodes qu'ils utilisent dans leur processus et leur position dans ce processus. Un total de 91 professionnels UX ont participé à l'étude. Les résultats montrent que la plupart des participants travaillent dans les grandes entreprises du secteur privé situées à Istanbul. L'intérêt des petites entreprises envers UX est plus par rapport aux moyennes entreprises, mais les organisations publiques ont révélé un intérêt limité. Les participants ne se sont pas décrits comme étant bien informés sur UX. Afin de soutenir leur auto-amélioration dans leur lieu de travail, les participants veulent enrichir les canaux de communication et les sources dans l'organisation. Les participants ne pouvaient pas assister aux activités nationales et internationales sur UX et ils n'avaient aucune communication avec les communautés UX nationales et internationales.

mots-clés: professionnels d'expérience utilisateur, expérience utilisateur (UX), Utilisabilité, Interaction homme-ordinateur

\section{Öz}

Bu çalışmanın amacı Türkiye'deki kullanıcı deneyimi profesyonellerinin profillerini, çalışma ortamlarını, çalışma sürecinde kullandıkları yöntemleri ve mevcut iş akışı içindeki konumlarını inceleyerek kullanıcı deneyimi ekosistemine yönelik kapsamlı bir analiz ortaya koymaktır. Çalışmada 91 kullanıcı deneyimi profesyoneli yer almıştır. Elde edilen bulgulara göre, katılımcıların çoğunlukla özel sektörde faaliyet gösteren, büyük ölçekli firmalarda çalışan ve İstanbul merkezli bir ekosistemin içerisinde yer aldıkları görülmüştür. Küçük ölçekli firmaların kullanıcı deneyimine ilgisi orta ölçekli firmalardan daha fazla olurken, kamu kurumlarının bu alanda oldukça sınırlı varlık gösterdiği belirlenmiştir. Katıııcıların kendilerini kullanıcı deneyimi konusunda yeterince bilgili görmedikleri tespit edilmiştir. Katılımcıların iş yaşamındaki gelişimlerini iyileştirmek için özellikle kurum içerisindeki iletişim kanallarını ve kaynaklarını zenginleştirmeyi istedikleri belirlenmiştir. Ayrıca katılımcıların gerek ulusal ve gerekse de uluslararası etkinliklere oldukça az katıım sağlayabildikleri, ulusal ve uluslararası kullanıcı deneyimi toplulukları ile etkin bir iletişimlerinin olmadığı görülmüştür.

anahtar kelimeler: kullanıc deneyimi profesyonelleri, kullanıc deneyimi, kullanılabilirlik, insan bilgisayar etkileşimi 


\section{Giriş}

Kullanıcı deneyimi kavramı, günümüzde sadece yazılım dünyasında değil, üretimden hizmet sektörüne kadar oldukça geniş bir yelpaze içerisinde kullanılmaktadır. Kullanıcıların kendilerine sunulan sisteme, hizmete veya ürüne karşı olan algı ve tepkilerinin tümü olarak ifade edilebilecek kullanıcı deneyimi (Uluslararası Standardizasyon Kuruluşu, ISO 9241-210), firmalara önemli ölçüde avantajlar sağlamaktadır. Kullanıc dostu dijital platformlar pozitif deneyimler sunarak müşterilerinin istedikleri işleri hızla, kolaylıkla ve keyifle yapmalarını mümkün kılmaktadır.

Türkiye'de kullanıcı deneyimi merkezli dijital ürün geliştirme süreci gün geçtikçe daha çok benimsenmekte ve yaygınlaşmaktadır. Bu sürece yönelik hızla büyüyen ilgi, alan içinde uzmanlaşan ve çalışan profesyonel sayısının da hızla artmasına yol açmaktadır. Literatürde farklı ülkelerde çalışan kullanıcı deneyimi profesyonellerinin profillerini ve çalışma süreçlerini inceleyen çalışmalar mevcuttur. Türkiye ölçeğinde ise her ne kadar yazılım geliştiricilerin (Inal ve Güner, 2016) veya yazılım firmalarının (Coşkan ve Onay Durdu, 2014) kullanılabilirlik ve kullanıcı deneyimine yönelik bilgi seviyesi, farkındalıkları ve meslek içi uygulamalarını araştıran çalışmalar olsa da, ekosistemin odağında yer alan kullanıcı deneyimi profesyonellerine yönelik bu konularda herhangi bir çalışma bulunmamaktadır. UXPA Türkiye gibi meslek örgütlerinin aktif üye sayıları da göz önünde bulundurularak yaklaşık 100 kadar kullanıcı deneyimi profesyonelinin çalıştı̆̆ı tahmin edilen söz konusu ekosistemin hızla geliştiği günümüzde, buradaki mevcut durumu merceği altına alan bir çalışmanın alana somut bir bilimsel katkısı olacağı gibi söz konusu uzmanlığın sağlıkı bir şekilde gelişimine yönelik somut öneriler sunacağı da açıktır.

Bu anlamda bu çalışma, Türkiye'deki kullanıcı deneyimi profesyonellerinin profillerini, çalışma ortamlarını, çalışma sürecinde kullandıkları yöntemleri ve mevcut iş akışı içindeki konumlarını incelemek suretiyle kullanıcı deneyimi ekosistemine yönelik kapsamlı bir analizi hedeflemektedir. Çevrim-içi bir anket vasıtasıyla Türkiye'deki tüm kullanıcı deneyimi profesyonellerine ulaşmak hedeflemiştir. Makalenin akışında sırasıyla teorik arka plan, yöntem, bulgular, tartışma ve sonuç bölümlerine yer verilmiştir.

\section{Teorik Arka Plan}

Kullanılabilirlik, kullanıcıya geliştirme süreçlerinde erken odaklanılması sayesinde, uygulamanın hedef kitle için uygun olup olmadığının, erken evrelerden itibaren kullanıcının nasıl kullanması gerektiğinin ve yazılımın kalite özelliklerinin belirlenmesi gibi ölçütlerde önemli bir rol oynamaktadır (Xenos, 2001). Kullanılabilirlik ve yazılım geliştirme arasındaki ilişkiye odaklanarak kullanılabilirlik aktivitelerinin yazııı geliştirmeye olan öneminin tasarımın kalitesine olan yansımalarını araştıran bir çalışmada (Juristo vd., 2007), kullanılabilirliğin yazılımın 
tasarımı aşamasında geliştirilen uygulamanın kalitesine katkı sağladığı ortaya konulmaktadır. Dolayısıyla, kullanıcı ile ne kadar erken iletişim kurulursa, ortaya çıkan uygulamaya duyulan memnuniyet de o derece iyi olacaktır (Anderson vd., 2001).

Günümüzde artık firmalar kendi bünyelerinde kullanılabilirlik ve kullanıcı deneyimi aktivitelerinden sorumlu olarak çalışan kullanıcı deneyimi profesyonellerini çalıştırmayı tercih etmektedirler. Kullanılabilirlik ve kullanıcı deneyimi kavramlarının dijital ürün tasarımı süreçleri için vazgeçilmez olması sonucunda kullanıc deneyimi profesyonelliği bir uzmanlık alanı olarak 1990'li yıllardan sonra ortaya çıkmış ve hızla büyümektedir. Bu yıllarda kurulan Kullanıcı Deneyimi Profesyonelleri Birliği (UXPA), Türkiye dâhil çok sayıda ülkede faaliyet gösteren ve kullanıcı deneyimi konusunda çalışan uzmanların yer aldığı bir birlik olarak öne çıkmaktadır.

Kullanılabilirlik ve kullanıcı deneyimi kavramlarının kavranışı, dijital ürün tasarımı süreçlerinde ilgili kavramlar etrafında geliştirilmiş olan yöntem ve tekniklerin kullanımı, konunun uzmanlarının bu süreçlerdeki rolü ve söz konusu süreçlerin kurumlar tarafından benimsenmesine odaklanan bir çok araştırmayı literatür içinde bulmak mümkündür. Literatür içinde yer alan ve ağırlıklı olarak anket ve derinlemesine görüşme yöntemleriyle gerçekleştirilmiş olan söz konusu çalışmalar yazııım geliştiricilerden tasarımcılara, kullanılabilirlik uzmanlarından kullanıcı deneyimi profesyonellerine kadar farklı katıımcı gruplarına odaklanmışlardır. Literatürde yer alan ve kullanılabilirlik uzmanlarına ve kullanıcı deneyimi profesyonellerine odaklanan çalışmalar dört temel kategori altında ele alınabilir.

Birinci kategoride kullanılabilirlik ve kullanıc deneyimi kavramlarının kavranışını inceleyen çalışmalar yer almaktadır. Örneğin Law vd. (2009) tarafından Finlandiya, Amerika, İngiltere ve Hollanda'dan 275 kişi ile birlikte yürüttükleri anket çalışmasına göre kullanıcı deneyimi, potansiyel kullanıcıların bir üründen elde edebilecekleri faydayı temsil eden; bağlama özel ve dinamik bir kavram olarak tanımlanmıştır. Bu anlamda, insan-bilgisayar etkileşimi disiplini içinde konumlandırımalı ve kullanıcı-merkezli tasarım sürecinin bir parçası olarak değerlendirilmelidir.

İkinci kategoride yer alan çalışmalar, kullanılabilirlik ve kullanıcı deneyimi kavramlarının kavranışını incelemekle birlikte ürün geliştirme süreçlerinde ilgili kavramların benimsenmesi önündeki engelleri de ortaya koymaktadır. Kullanılabilirlik ve kullanıcı deneyimi nispeten yeni bir uzmanlık alanını temsil ettiğinden dolayı özellikle 2000 yılından önce yapılan çalışmalarda örneklem ağırlıklı olarak yazılım geliştiricilerden oluşmaktadır.

Bu kategorideki ilk çalışmayı gerçekleştiren Dillon vd.'ye (1993) göre kurumların sadece beşte birinde kullanıcı araştırmaları yapmaya olanak sağlayacak 
kaynaklar bulunmakta olup, ürün geliştirme süreçlerinde test yapmak zorunlu olmamakta ve çoğu zaman bu işe zaman ayrılmamaktadır. Takip eden çalışmalar benzer bulguları yinelemekle birlikte, dijital ürün geliştirme sürecinde çalışan ekiplerin gerçek kullanıcılarla temasının olmaması ve birbiri arasında sağlıklı iletişim kuramaması (Poltrock ve Grudin, 1994), pazarlama gibi farklı birimler tarafından söz konusu süreçlere yönelik destek sağlanmaması (Bekker ve Vermeeren, 1996) ve üst yönetimin kullanılabilirliğin sağlayacağı katkılar konusunda ikna edilmek zorunda olunması (Borgholm ve Madsen, 1999) gibi sorunları ortaya koymaktadır.

2000 yılından sonra gerçekleştirilen çalışmalarda örneklem dâhilinde kullanılabilirlik ve kullanıcı deneyimi profesyonellerini görmek mümkündür. Bu bağlamda karşımıza çıkan ilk çalışmada Catarci vd. (2002), kullanılabilirliğin sağladığı değerlerin kurumsal seviyede kabullenilmesini engelleyen iki temel problem kategorisini tanımlamaktadır: Hedef kitleyi oluşturan kullanıcıların temsil edilmediği süreçleri öne çıkartan organizasyon merkezli sorunlar ve kullanıcıyı bir rakip olarak gören tasarımcıların gerekli yöntemlere başvurmaktan kaçındığı kültürel/metodolojik sorunlar. Illerleyen yıllarda gerçekleştirilen çalışmalar kullanıcı deneyimini kullanılabilirliği de kapsayan yeni bir disiplin ve uzmanlık olarak öne çıkartsa da, sorunların değişmediğini göstermektedir. Yazıımcının meseleye yönelik tutucu yaklaşımının kullanıcı deneyimi profesyonellerinin ürün geliştirme sürecinin her fazına entegre olmasını engellemesi, kullanıcı merkezli bir süreci destekleyecek kaynakların sınırlı olarak sunulması ve gerçek kullanıcılara erişim zorluğu yine öne çıkan sorunlardır (Chilana vd., 2011; Ardito vd., 2011; Hussein vd., 2012; Hussein vd., 2013).

İlgili literatürün üçüncü kategorisinde yer alan çalışmalar kullanılabilirlik ve kullanıcı deneyimi profesyonellerinin ürün geliştirme sürecindeki rol ve sorumluğunu ortaya koymayı hedeflemişlerdir. Söz konusu perspektif, ilgili kavramların benimsenmesi sürecinde ortaya çıkan sorunları da tespit etme olanağı sağlamaktadır. Kullanılabilirlik uzmanı, etkileşim tasarımcısı gibi uzmanlaşmış pozisyonları istihdam eden ve bu anlamda olgun bir kullanıcı deneyimi ekosistemine sahip Danimarka gibi ülkelerde kullanıcı araştırmaları temel bir motivasyon kaynağı olarak öne çıkmaktadır (Borgholm ve Madsen, 1999). Nitekim bu ülkelerde saha çalışmalarını sürdürmek konusunda somut bir istek ve özgüven söz konusu olup kullanıcı ile duygudaşlık değerli bir kavram olarak vurgulanmaktadır. Boivie vd. (2006) tarafından İsveç'te 13 kullanılabilirlik tasarımcısı ile derinlemesine görüşme tekniğiyle gerçekleştirilen araştırmaya göre söz konusu tasarımcılar kendilerini kullanıcıların temsilcisi rolünde görmektedirler.

Bununla birlikte, kurumsal seviyede sorunlar sürmektedir. Yazılım mühendisleri ve kullanılabilirlik/kullanıcı deneyimi profesyonelleri arasındaki tüm sürece yayılan eşgüdümlü bir iletişimin kurulamaması (Jerome ve Kazman, 2005), uzmanlıkları dışında olduğu halde yazılım mühendislerinin arayüz tasarımında da inisiyatif almak durumunda kalması (Vukelja vd., 2007) ve proje yönetim desteğinin verilmemesi (Gulliksen vd., 2004) temel sorunlar olarak dikkat çekmektedir. Smith 
vd. (2007) tarafından yapılan çalışma, kullanıcı deneyiminin kurumsallaşmasına yönelik üçayaklı bir çözüm önerisi sunması itibariyle önemlidir. Öncelikle hedef kültüre uygun kavram ve yöntem setlerinin sunulması kritiktir. Bunu takiben bu yeni disiplin etrafında hem endüstri hem de akademi seviyesinde yeni bir ulusal yapının kurulmasını teşvik etmek gerekmektedir. Son olarak endüstri içinde etkili kullanıcı deneyimi pratiklerini hayata geçirmek gerekmektedir.

Literatür içindeki dördüncü ve son kategoride yer alan çalışmalar kullanıcı deneyimi profesyonellerinin bireysel olarak sahip oldukları bilgi ve kullandıkları teknik ve yöntemleri ortaya koymaya odaklanmıştır. Kullanıc deneyimi merkezli süreçlerde belli metriklerin ölçülmesinin önemi vurgulanmakla birlikte pratikte bu metrikler ölçülmemektedir (Vredenburg vd., 2002). Danimarka gibi bu konuda yetkin ülkelerde dahi kullanıcı deneyimi profesyonellerinin teorik bilgisinin sadece temel teorik yaklaşımlarla sınırlı olduğu gözlenmiştir (Clemmensen, 2005). Uzmanların yaygın olarak kullanılan temel teknik ve yöntemleri bildiği, ancak alandaki mevcut geniş yöntem setinden hakkıyla faydalanmadığı tespit edilmiştir (Roche vd., 2014).

Türkiye'de son yıllarda gelişim gösteren kullanıcı deneyimi alanında çalışan profesyonellerin de bu kapsamda, gerek mevcut bilgileri gerekse de iş yaşamlarında uyguladıkları yöntemler ve kullandıkları araçların ortaya konulması, kullanıcı deneyimi ekosisteminin ulusal ölçekte anlaşılması açısından kritiktir. Ancak, Türkiye'de kullanıcı deneyimi profesyonellerinin profillerini, çalışma ortamlarını ve mevcut iş akışı içindeki konumlarını inceleyen herhangi bir araştırma mevcut değildir. Bu anlamda çalışmamızın ilgili literatüre doğrudan katkı sağlayacağı öngörülmektedir.

\section{Yöntem}

Bu çalışma, Türkiye'deki kullanıcı deneyimi profesyonellerinin profillerini, çalışma ortamlarını, çalışma sürecinde kullandıkları yöntemleri ve mevcut iş akışı içindeki konumlarını inceleyerek, kullanıcı deneyimi ekosistemine yönelik kapsamlı bir analiz yapmayı amaçlayan betimsel bir anket çalışmasıdır. Çalışma, uluslararası bir araştırma projesinin Türkiye ayağında toplanan verileri kapsamaktadır. Uluslararası araştırma projesi kapsamında Türkiye, Danimarka, Finlandiya, Malezya ve Fransa'da çalışan kullanıcı deneyimi profesyonellerinden toplanan veriler, kültürler arası bir yaklaşımla karşılaştırmalı olarak ele alınacaktır.

2000'li yıllardan sonra örneklem dâhilinde kullanıcı deneyimi profesyonellerine yönelik yapılan araştırmalar genellikle dar bir kapsam içerisinde konuyu ele almaktadır. Bu çalışma ise, önceki benzer çalışmaların kapsamları bir araya getirilerek oluşturulmuş ve konunun derinlemesine analizine olanak sağlayacak büyüklükte bir anket çalışması olarak kurgulanmıştır. Anket, literatürde yer alan önceki çalışmalarda (Bygstad vd., 2008; Clemmensen, 2003; Jerome ve Kazman, 2005; Hussein vd., 2012; Roche vd., 2014; Vukelja vd., 2007 gibi) 
kullanıcı deneyimi profesyonelleri ve yazılım geliştiricilerin profillerini, kullanıcı deneyimi konusundaki bilgi seviyelerini ve çalışma süreçlerini incelemek amacıyla oluşturulan ve benzer çalışmalarda yine referans olarak başvurulan anketlerden faydalanılarak geliştirilmiştir. Bu kapsamda 7 bölümden ve 62 sorudan oluşan bir anket geliştirilmiştir. Ankette yer alan sorular, çoktan seçmeli ve açık uçlu soru tiplerinden oluşmaktadır.

Kullanıcı deneyimi profesyonellerinin demografik, eğitim ve çalışma deneyimi gibi profil bilgileri; çalıştıkları kuruma dair yapısal bilgiler; kullanılabilirlik ve kullanıcı deneyimi konusundaki temel bilgi ve farkındalıkları; kullandıkları yöntem ve araçlar; bu kapsamda yapılan çalışmaların kurumlardaki iş yapış biçimlerine entegrasyonu ve yerel kullanıcı deneyimi topluluğunun özellikleri ayrı başlıklar altında incelenmiştir. Araştırma kapsamında yukarıda bahsi geçen her bir başlığın kullanıcı deneyimi ekosisteminin gelişimi üzerindeki etkisini detaylı olarak ortaya koymak hedeflenmiştir.

Çalışmada elde edilen veriler 8 haftalık bir süre içerisinde çevrim-içi anket üzerinden toplanmıştır. Anket doldurulmadan önce, katılımcılara çalışma ve anketteki sorular hakkında bilgi vermek amacıyla bir bilgilendirme sayfası hazırlanmıştır. Mümkün olduğunca çok kullanıcı deneyimi profesyoneline ulaşmak için anket öncelikle çalışmayı yürüten araştırmacıların da üye oldukları "Kullanıcı Deneyimi Profesyonelleri Birliği (UXPA) Türkiye Birimi" meslek örgütünün e-posta listelerine gönderilmiş; "Kullanıc Deneyimi Profesyonelleri Birliği (UXPA) Türkiye Birimi" nin Twitter, Linkedin gibi resmi sosyal medya hesapları üzerinden de ankete yönelik çağı dolaşıma sokulmuştur. Buna ek olarak Türkiye'de ilgili profesyonellerin aktif olarak yeraldığı Alternatif Bilişim Derneği, Engelsiz Bilişim Platformu gibi sivil toplum örgütlerinin listelerine de anket çağrısı gönderilmiştir. Ayrıca, çalışmayı yürüten araştırmacıların kendi kişisel e-posta listeleri ve sosyal medya hesapları üzerinden de anketin dolaşıma sokulması sağlanmıştır. Kullanıcı deneyimi profesyonellerine ilk e-posta gönderildikten sonraki her iki haftalık periyotlarda hatırlatma e-postaları atılmış, çalışma hakkında tekrar bilgi verilerek katılımcı sayısının arttııııması amaçlanmıştır.

\section{Bulgular}

Bu bölümde anket çalışmasının sunduğu detaylı bulgulara yer verilmiştir. Bulgular anketi oluşturan bölüm başıkları altında ayrı ayrı ele alınmıştır.

\section{Kullanıcı Deneyimi Profesyonellerinin Profili}

Çalışmada, Türkiye'de kullanıcı deneyimi profesyoneli olarak çalışan 91 katıımcı yer almıştır. Yaş ortalaması 32 olarak belirlenen katılımcıların 57'si erkek, 34'ü kadındır. Katılımcıların büyük bölümü $(n=78)$ bir kurum bünyesinde çalıştıklarını ifade ederken, 8 katıımcı girişimci, 3 katılımcı serbest çalışan, 2 katılımcı ise öğrenci olduğunu belirtmiştir. Toplam iş tecrübesi ortalama 9 yıl 
olan katılımcıların, toplam kullanıcı deneyimi alanındaki iş tecrübesi ortalama 4 yıl, mevcut unvanlarındaki iş tecrübesi ise ortalama 4 yıl'dır. Katılımcıların en son tamamladıkları eğitim seviyelerine bakıldığında, 3'ü lise, 41'i lisans, 37'si yüksek lisans ve 10'u doktora olarak görülmektedir (Şekil 1).

Şekil 1. Katılımcıların eğitim seviyeleri

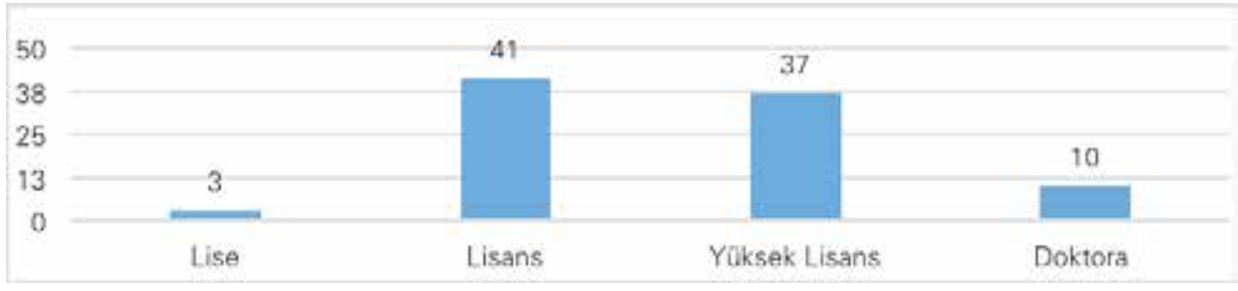

Çalışmada yer alan katılımcıların önemli bölümü medya ve iletişim ( $n=22)$, bilgisayar ve bilişim (enformatik) ( $n=17)$, işletme ve yönetim $(n=9)$, etkileşim, medya ve iletişim tasarımı $(n=9)$, mühendislik $(n=5)$, endüstriyel tasarım $(n=4)$, güzel sanatlar $(n=4)$ ve eğitim bilimleri $(n=4)$ alanlarından mezun olmuştur. Bunun dışında mimarlık, ekonomi, psikoloji, turizm, matematik, antropoloji, kamu yönetimi, pazarlama, sosyal bilimler, tarım ve fizik gibi alanlar da katılımcıların mezun oldukları diğer temel alanlardır.

Yabancı dil bilgisi açısından, katılımcıların büyük bölümü ( $n=83$ ) İngilizce'yi bildiğini belirtirken, bunu sırasıyla Almanca $(n=17)$, Fransızca $(n=12)$ ve İtalyanca $(n=4)$ takip etmektedir. 22 katılımcı iki ve daha fazla yabancı dil bilgisine sahip olduğunu belirtmiştir. Sadece 8 katılımcı herhangi bir yabancı dil bilgisine sahip olmadığını ifade etmiştir. Katılımcıların çalıştıkları kurumların organizasyonel hiyerarşisindeki mevcut pozisyonuna bakıldığında, orta/alt yönetim (proje yöneticisi, takım lideri vb.) olarak 30 , konu alan uzmanı olarak 29 , üst yönetim (kurum yöneticisi vb.) olarak 17, başlangıı̧ seviyesinde 7 ve herhangi bir işte çalışmayan 3 katıımcı olduğu görülmüştür.

Katıımcıların çalıştıkları kurumlarda kullandıkları unvanları çeşitlilik göstermektedir. Buna göre, önemli bir bölümünün kullanıcı deneyimi tasarımcısı $(n=15)$, akademik personel $(n=12)$, ürün yöneticisi $(n=10)$, proje yöneticisi $(n=10)$ ve kullanıcı deneyimi yöneticisi $(n=10)$ unvanlarına sahip olduğu görülmüştür. Ayrıca, kullanıcı deneyimi araştırmacısı, servis tasarımcısı, süreç yöneticisi, etkileşim tasarımcısı, kullanılabilirlik araştırmacısı, kullanıcı deneyimi stratejisti gibi oldukça farklı isimlerde unvanların kullanıldığı belirlenmiştir. 


\section{Kullanıcı Deneyimi Profesyonellerinin Kurumlarına Yönelik Bilgiler}

Çalışmada yer alan katııımcıların büyük bölümü $(n=80)$ İstanbul'da çalışmaktadır. Ankara'da bulunan az sayıdaki çalışana $(n=6)$ ek olarak Aksaray, Bursa, Gaziantep ve Mardin gibi şehirlerde de katılımcıların çalıştıkları görülmüştür. 51 katıımcı büyük ölçekli bir firmada kurum içi kullanıcı deneyimi çalışanı olarak görev aldığını, 7 katııımcı ise tek kişilik kullanıcı deneyimi danışmanlık firmasında çalıştığını ifade etmiştir. Diğer katıımcılar, üniversite, tasarım firması, kamu kurumu ve yazıım firması gibi organizasyon türlerinde çalıştığını belirtmişlerdir.

Katılımcıların çalıştıkları kurumların faaliyet alanları değişkenlik gösterse de, bilgi ve iletişim $(n=36)$, eğitim $(n=20)$ ve finansal ve sigorta faaliyetleri $(n=16)$ öne çıkan alanlardandır. Bunları sırasıyla toptan ve perakende satış $(n=7)$, profesyonel, bilimsel ve teknik faaliyetler $(n=7)$, imalat ve üretim $(n=6)$, güzel sanatlar ve eğlence $(n=6)$ ve gayrimenkul faaliyetleri $(n=5)$ takip etmektedir.

Ulusal ölçekte faaliyet gösteren firmalarda çalışan katılımcı sayısı 41, uluslararası ölçekte faaliyet gösteren firmalarda çalışan katılımcı sayısı ise 50 olarak belirlenmiştir. Katılımcıların büyük bölümü $(n=70)$ özel sektörde faaliyet gösteren bir kurumda çalışırken, akademik kurumda çalışanların sayısı 12, kamu kurumunda çalışanların sayısı ise 8'dir. Katılımcıların çalıştıkları kurumların büyüklüğüne bakıldığında, çalışan sayısının 250 kişiden fazla olduğu büyük ölçekli kurumlarda çalışanların sayısı 58, çalışan sayısının 250 kişiden az olduğu orta ölçekli kurumlarda çalışanların sayısı 14 ve çalışan sayısının 50 kişiden az olduğu küçük ölçekli kurumlarda çalışanların sayısı 18'dir (Şekil 2).

Şekil 2. Katılımcıların çalıştıkları kurumların büyüklükleri

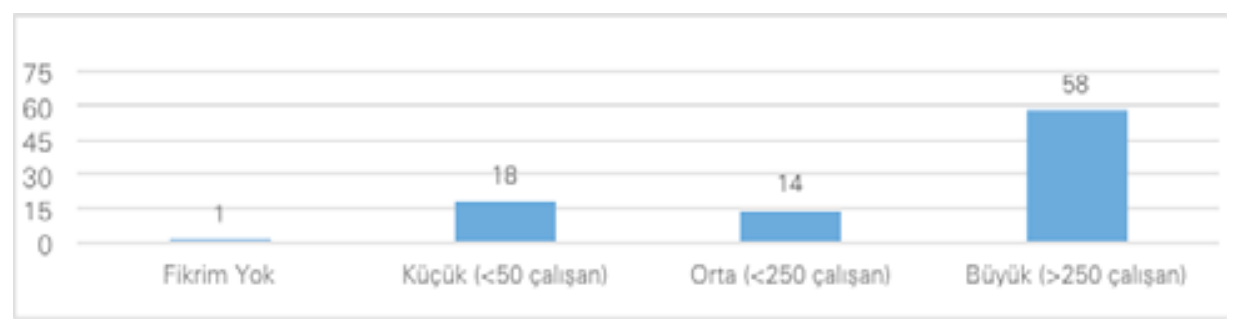

Katılımcıların çalıştıkları kurumların CMMI, SPICE veya ISO benzeri bir olgunluk (kalite) sertifikasına sahip olup olmadığına yönelik soruya, 22 katılımcı evet cevabı verirken, 22 katılımcı ise hayır cevabı vermiştir. Katılımcıların yarısından fazlası $(n=47)$ bu konuda herhangi bir bilgisinin olmadığını ifade etmiştir. Üzerinde çalıştıkları projelerde son 2 yıl içerisinde kullandıkları yazılım, sistem veya ürün geliştirme yöntemi olarak, sırasıyla çevik/yalın $(n=59)$, şelale yöntemi $(n=29)$ ve hızlı prototiplendirme $(n=26)$ yöntemlerinin kullanıldığı görülmüştür. 25 katıımcı ise bu konuda herhangi bir fikrinin olmadığını ifade etmiştir (Şekil 3). 
Şekil 3. Katılımcıların çalıştıkları projelerde kullandıkları yöntemler

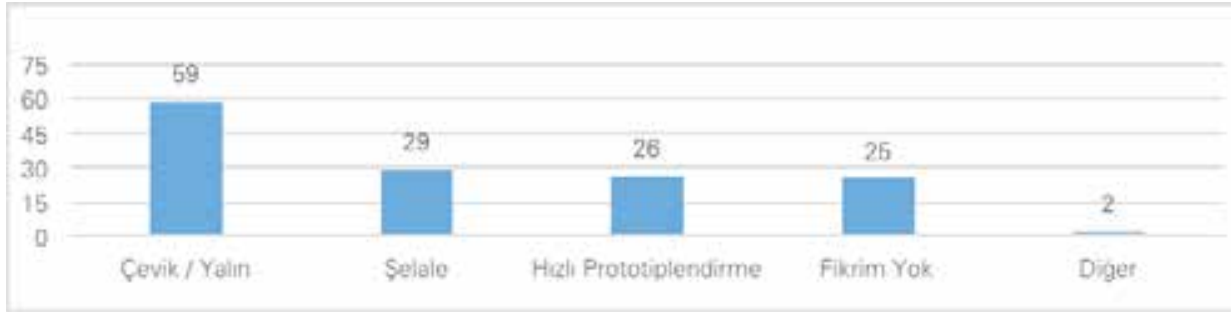

Kurumların kullanıcı deneyimi profesyonellerine yaptıkları yatıımın ve istihdam politikalarının ortaya çıkarılması amacıyla, katılımcılara kurumlarında çalışan kullanıcı deneyimi profesyonellerinin sayısı sorulmuştur. Buna göre, katılımcıların önemli bir bölümü $(n=43)$ kurumlarında $0-5$ arası kullanıcı deneyimi profesyoneli çalıştığını ifade ederken, 13 katılımcı kurumlarında sadece 1 kullanıcı deneyimi profesyonelinin bulunduğunu belirtmiştir. $25 \mathrm{katılımcı} \mathrm{ise} \mathrm{bu}$ konuda herhangi bir fikir beyan etmemiştir. Organizasyonların kullanıcı deneyimi konusundaki tecrübeleri ile ilgili olarak ise, katılımcıların önemli bölümü $(n=46)$ kurumlarının 0-5 yıl arası tecrübeye sahip olduğunu belirtmiştir. 32 katıımcı bu konuda herhangi bir fikir beyan etmemiştir. Kullanıc deneyimi konusunda kurumların son yıllarda yeni yeni yatııım yapmaya başladığı ve bu alanda yakın zamanda personel çalıştırmaya başladığı görülmektedir (Şekil 4).

Şekil 4. Katılımcıların çalıştıkları kurumların kullanıcı deneyimi konusundaki tecrübelerine yönelik beyanları

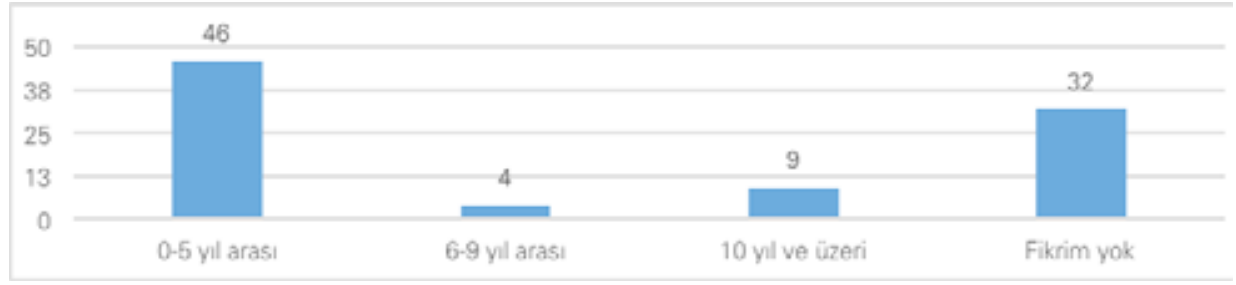

Çalışmada yer alan katılımcıların görev aldıkları son projelerinde proje ekibinde çalışan kullanıcı deneyimi profesyoneli sayılarına bakıldığında, büyük çoğunluğunun ( $n=55$ ) 0-5 kişi cevabı verdiği belirlenmiştir. Altı katılımcı 6-9 kişi cevabı verirken, geri kalan katılımcılar $(n=4)$ ise 10 yıl ve üzeri cevabı vermiştir. 26 katılımcı bu konuda herhangi bir fikir beyan etmemiştir. 


\section{Kullanıcı Deneyimi Profesyonellerinin Kullanıcı Deneyimi Konusunda Temel Bilgi ve Farkındalık Seviyeleri}

Çalışmada yer alan katıımcıların kullanılabilirlik ve kullanıcı deneyimi konularındaki temel bilgi seviyelerini ölçmek için kendilerine bu kavramlara yönelik tanımlar sorulmuştur. Buna göre katılımcıların büyük bölümünün $(n=75)$ kullanılabilirliği "Bir ürünün ne derecede etkin, verimli ve tatmin edici bir kullanım sunduğunu tanımlamaktadır" olarak tanımladıkları görülmüştür. 6 katıımcı "Ürün ve onu sahiplenen kurum arasındaki uyumu tanımlamaktadır" şeklinde tanımlarken, 10 katılımcı ise her iki tanımı da eşit eşit derecede önemli gördüğünü belirtmiştir.

Kullanıc deneyimi konusunda ise 35 katılımcı kullanıc deneyimini "Bir ürünün algılanan albenisi, kullanım kolaylığı, fayda sağlaması ve kullanılma sıklığıdır" olarak tanımlarken, 28 katııımcı "Elemanların kompozisyonu, duyusal özellikleri, ilgili duygular ve bağlamın birleşiminden oluşan deneyimdir" şeklinde tanımlamıştır. 28 katıımcı ise her iki tanımı eşit derecede önemli gördügünü ifade etmiştir.

Çalışmada yer alan katıımcıların iş yaşamlarında kullandıkları teori veya yöntemlere yönelik bilgi seviyelerine bakıldığında, büyük bölümünün "Kullanıcı Deneyimi" ( $n=78)$, "Kullanılabilirlik" ( $n=72)$ ve "Kullanıcı Merkezli Tasarım" $(n=57)$ cevabı verdiği görülmüştür. Bunları sırasıyla, "Sürdürülebilir Tasarım" $(n=33)$, "Zihinsel Modeller" ( $n=24)$, "Değerlere Duyarlı Tasarım" $(n=17)$, "Bilişsel İş Analizi" ( $n=15)$, "Etkileşim Yöntembilimi" ( $n=12)$, "Kapsayıcı Tasarım" ( $n=10)$ ve "Tasarım Aktivizmi" ( $n=10)$ takip etmiştir.

Katılımcıların önemli bir bölümünün $(n=33)$ son 12 ay içerisinde kullanıcı deneyimi alanıyla ilgili ulusal herhangi bir etkinliğe katılmadığı belirlenmiştir. Bir etkinliğe katılı̆̆ını ifade eden katılımcı sayısı 14 olurken, iki etkinliğe katılanların sayısı 14 ve üç etkinliğe katılan katıımcı sayısı ise 13 olmuştur. Son 12 ay içerisinde katıldıkları ulusal etkinlik sayısı ortalama 2.12'dir. Buna karşın son 12 ay içerisinde katılım sağlanan uluslararası etkinlik sayısının daha düşük olduğu belirlenmiştir. Katılımcıların büyük bölümü $(n=64)$ herhangi bir uluslararası etkinliğe katıım sağlamadığını belirtirken, bir etkinliğe katıldığını belirten katıımcı sayısı 15, iki etkinliğe katılanların sayısı 7 ve üç etkinliğe katılan katılımcı sayısı 2 'dir. Son 12 ay içerisinde katıldıkları uluslararası etkinlik sayısı ortalama 0.56 'dır. Bu da katıımcıların gerek ulusal ve özellikle de uluslararası etkinliklere katıım sağlama imkânlarının fazla olmadığı sonucunu ortaya koymaktadır (Şekil 5). Ayrıca, Türkiye dışında kullanıcı deneyimi konularında (uluslararası kullanılabilirlik testi gibi) herhangi bir çalışma yapmadığını belirten katılımcı sayısı da yine çalışmadaki katılımcıların büyük çoğunluğunu $(n=78)$ oluşturmaktadır. Bu sonuçlar, Türkiye'de çalışan kullanıcı deneyimi profesyonellerinin uluslararası kullanıcı deneyimi toplulukları ile etkileşiminin ve uluslararası ölçekte profesyonel tecrübelerinin fazla olmadığını göstermektedir. 
Şekil 5. Katılımcıların son 12 ay içerisinde katıldıkları ulusal ve uluslararası etkinlik sayıları ve ortalaması

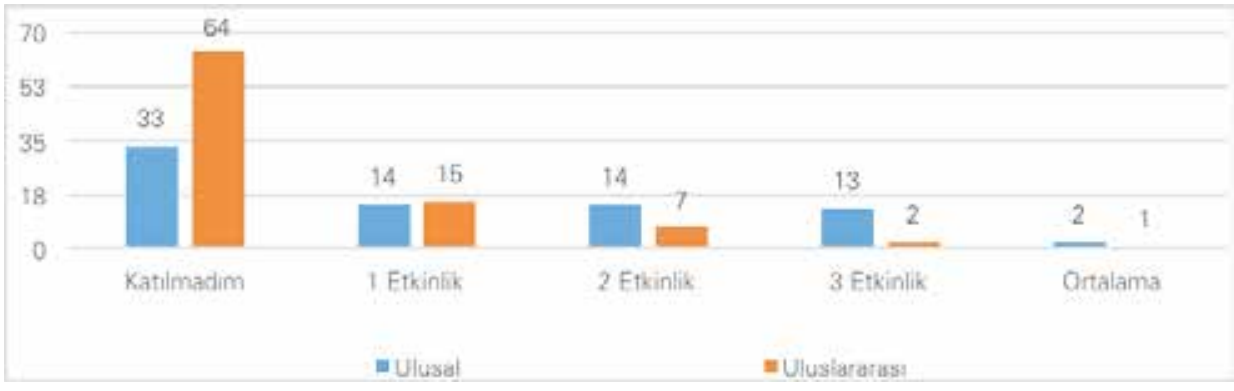

Katıımcıların uzmanlık alanlarına ilişkin farkındalıklarına yönelik olarak, kullanılabilirlik ve kullanıc deneyimi kelimelerinin Türkiye'de ilk defa ne zaman kullanılmaya başlandığı kendilerine sorulmuştur. Buna göre kullanılabilirlik kelimesinin en eski 1945, en yeni 2015 yılında kullanılmaya başlandığı belirtilirken, kullanıcı deneyimi kelimesinin ise en eski 1980, en yeni 2015 yılında kullanılmaya başlandığı ifade edilmiştir. Katılımcıların kullanıcı deneyimine yönelik ulusal farkındalığın kullanılabilirlik kavramına göre daha yeni olduğu yönünde görüşleri olduğu görülmüştür. Ayrıca çalışmada yer alan katıımcıların neredeyse tamamına yakını ( $n=84)$ kullanıcı deneyimi ile ilgili yasal düzenlemeler veya gereksinimler hakkında bilgisinin olmadığını belirtmiştir.

Katılımcıların önemli bir bölümünün $(n=65)$ insan bilgisayar etkileşimi alanında herhangi bir eğitim almadığı belirlenmiş̧ir. Sadece 26 katılımcı eğitim aldığını ifade ederken, bu konuda tez yazan katılımcı sayısı 12, proje yapan katılımcı sayısı 6 ve sertifika sahibi olan katılımcı sayısı da 2'dir (Şekil 6). "Insan Bilgisayar Etkileşimi" ( $n=8)$, "Etkileşimli Medya Tasarımı" ( $n=7)$ ve "Kullanılabilirlik" $(n=4)$ dersleri katıımcıların bu alanda aldıkları ders isimleridir. Ayrıca "Araştırma Yöntemleri", "Tasarım Teorisi", "Bilgi Tasarımı", "Görsel Kültür" ve "Etkileşim Tasarım Yönetimi" de yine katılımcılar tarafından alınan diğer derslerdendir. Bunun yanında katılımcıların önemli bir bölümünün $(n=68)$ kullanıcı deneyimi alanında hizmet-içi eğitim veya bir kurs almadığı belirlenmiştir.

Şekil 6. Katılımcıların insan bilgisayar etkileşimi alanındaki eğitimleri

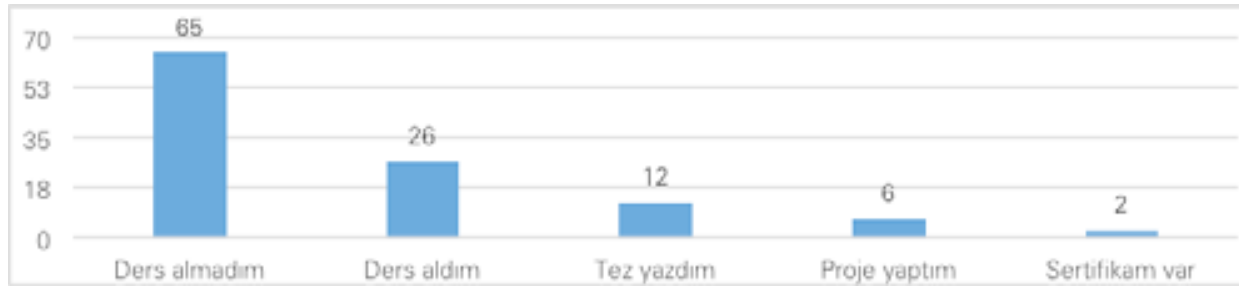


Kullanıcı deneyimi alanındaki gelişmeleri katıımcıların nasıl takip ettikleri kendilerine sorulmuş ve alınan cevaplara göre blog sayfaları $(n=68)$ ve teknoloji haberleri ve dergileri $(n=61)$ en fazla takip edilen araçlar olarak öne çıkmıştır. Kitaplar $(n=44)$, bilimsel makaleler $(n=42)$, çevrimiçi tartışma forumları ve web siteleri $(n=39)$, kullanıcı deneyimi alanında konferans, seminer ve çalıştay vb. etkinlikler $(n=26)$ ve kurslar $(n=15)$ da kullanıcı deneyimi alanındaki gelişmeleri takip etmek için tercih edilen araçlardandır. Katılımcıların en sık katıldığı etkinlikler ise; UX Alive $(n=13)$, UXPA Turkey $(n=10)$, UXIstanbul $(n=8)$ ve UX Cafe $(n=3)$ olarak belirlenmiştir. Çalışmada yer alan sadece 6 katılımcı kullanıcı deneyimi alanını takip etmediğini ifade etmiştir (Şekil 7).

Şekil 7. Katıımcıların kullanıcı deneyimi alanındaki gelişmeleri takip ettikleri araçlar

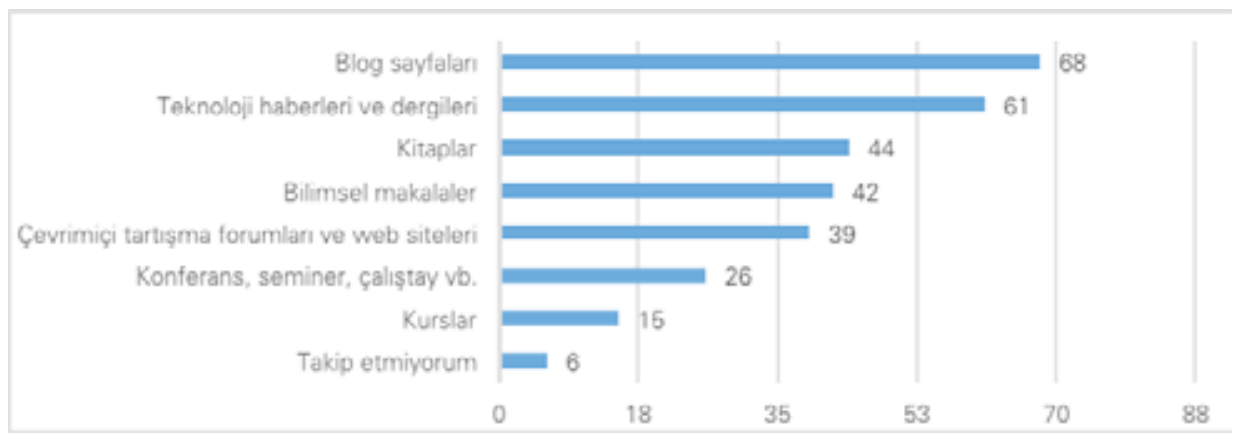

Katılımcıların kullanıcı deneyimi alanına yönelik kendi bilgi seviyelerini değerlendirmeleri istendiğinde, bilgi seviyesini çok bilgili olarak beyan eden katıımcı sayısı 9 olurken, bilgisini az bilgili olarak beyan eden katılımcı sayısı 8'dir. 31 katılımcı ise kendi bilgi seviyesini orta seviyede olarak belirtmiştir.

Kullanıcı Deneyimi Profesyonelleri Tarafından Kullanılan Yöntem ve Araçlar

Çalışmada yer alan katıımcıların büyük bölümünün $(n=63)$ görev aldıkları projelerde kullanıcılarla yüz yüze iletişime geçtiği belirlenmiştir. Bu konuda bir çalışma yapmadığını ifade eden katılımcı sayısı ise $23^{\prime}$ tür. Katılımcıların büyük bölümü ( $n=57)$ genel olarak kullanılabilirlik testi yaptığını ifade ederken, 34 katıımcı ise herhangi bir kullanılabilirlik testi yapmadığını belirtmiştir. Kullanılabilirlik testi yapan katılımcıların, uygulama veya ürünü yayına almadan önce ortalama 7 kullanılabilirlik testi yaptığı, son projelerinde yaptıkları kullanılabilirlik testlerine ise ortalama 22 kullanıcının katılı̆̆ı belirlenmiştir.

Katılımcıların kullanılabilirlik testi için kullanııları nası belirlediklerine yönelik sorulan soruya verdikleri cevaplara göre, 28 katılımcı kendi imkânları ile kullanıcıları belirlediklerini söylerken, bu konuda hizmet veren ajanslar üzerinden belirleyen katılımcı sayısı 24'tür. Bunların dışında, müşteriler arasından seçerek 
$(n=5)$, arkadaşları $(n=2)$ veya meslektaşlarından $(n=2)$ destek alarak kullanılabilirlik testi için kullanıcıların belirlendiği ifade edilmiştir.

Geçen yıl içerisinde kullanıcı deneyimi konusunda gerçekleştirilen aktivitelere bakıldığında, katılımcıların çoğunluğu kullanıcı araştırması ( $n=53)$, wireframing $(n=49)$, mockup $(n=48)$, memnuniyet anketi $(n=48)$ ve rakip analizi ( $n=47)$ aktivitelerini gerçekleştirdiğini belirtmiştir. Buna karşın, yönlendirmeli olarak uzaktan yürütülen kullanılabilirlik testi $(n=5)$, psikofizyolojik çalışmalar $(n=6)$, yaşam laboratuvarları $(n=7)$, yönlendirmesiz olarak uzaktan yürütülen kullanılabilirlik testi $(n=14)$, fikir geliştirme $(n=21)$ ve göz izleme çalışmaları $(n=26)$ katılımcılar tarafından en az yürütülen aktiviteler olarak öne çıkmıştır.

Katıımcıların büyük çoğunluğunun kullanıcılardan hızı geri bildirim almak için anket $(n=50)$ ve e-posta $(n=48)$ gibi araçları kullandıkları belirlenmiştir. Bunları sırasıyla A/B testi $(n=25)$ ve sosyal medya $(n=25)$ izlerken, Silverback $(n=11)$, Treejack $(n=8)$ ve Crazyegg $(n=6)$ de katılımcıların kullandığı diğer araçlardır. Sadece 7 katılımcı kullanıcılardan hızlı geribildirim almak için herhangi bir araç kullanmadığını ifade etmiştir.

Uzaktan yürütülen kullanılabilirlik testi için kullandıkları araçlarda, Treejack $(n=8)$, Crazyegg $(n=6)$ ve UserTesting.com $(n=5)$ öne çıkmıştır. Buna karşın, katılımcıların oldukça büyük bir bölümü $(n=64)$ uzaktan yürütülen kullanılabilirlik testini yapmadığını ifade etmiştir. İş yaşamları içerisinde sıklıkla kullanma ihtiyacı duydukları düşük ve yüksek sadakatli prototiplendirme araçlarına yönelik uygulamalarına bakıldığında; düşük sadakatli prototiplendirme için kâğıt prototiplendirme $(n=33)$, Photoshop $(n=25)$, Balsamiq Mockups $(n=24)$, Sketch $(n=24)$ ve Axure $(n=14)$ en sık kullanılan araçlardır. 25 katılımcı herhangi bir düşük sadakatli prototiplendirme aracı kullanmadığını belirtmiştir. Yüksek sadakatli prototiplendirme aracı olarak ise Photoshop $(n=26)$, Illustrator $(n=23)$, HTML+CSS $(n=21)$, Invision $(n=18)$ ve Axure $(n=17)$ en sık kullanılan araçlardan olurken, 23 katılımcı herhangi bir yüksek sadakatli prototiplendirme aracı kullanmadığını belirtmiştir.

\section{Kullanıcı Deneyimi Çalışmalarının Entegrasyonu}

Katılımcıların çalıştıkları organizasyonlardaki farklı unvan ve sorumluluklarda çalışanların kullanıcı deneyimini hangi seviyede bildikleri kendilerine sorulmuştur. Özellikle üst yönetim, proje yönetimi ve geliştiricilerin kullanıcı deneyimi konusunda bilgi sahibi olduğunu, proje içerisinde yer alan müşteri destek ve pazarlama gibi destek bölümlerinde çalışanların bu konuda bilgi sahibi olmadıklarını ifade etmişlerdir (Tablo 1). 
Tablo 1. Katılımcıların kurumlarındaki farklı unvanların kullanıcı deneyimi bilgisine yönelik beyanları

\begin{tabular}{lllllll}
\hline & 1 (az bilgili) & 2 & 3 & 4 & 5 (çok bilgili) & Uygun Değil \\
\hline Üst Yönetim & 16 & 17 & 21 & 21 & 12 & 4 \\
\hline Proje Yönetimi & 9 & 20 & 24 & 23 & 13 & 2 \\
\hline Geliştiriciler & 11 & 21 & 23 & 19 & 15 & 2 \\
\hline Tasarımcılar & 4 & 11 & 11 & 29 & 33 & 3 \\
\hline $\begin{array}{l}\text { Kullanıcı Deneyimi } \\
\text { Profesyonelleri }\end{array}$ & 4 & 3 & 6 & 22 & 43 & 13 \\
\hline Müşteri Destek & 19 & 32 & 11 & 4 & 8 & 17 \\
\hline Pazarlama & 11 & 18 & 21 & 19 & 9 & 13 \\
\hline
\end{tabular}

Kurumlarında yürütülen projelere katılımcıların ne zaman ve hangi aşamada dâhil edildiklerine yönelik olarak, büyük bölümünün $(n=58)$ projenin başlangıcından tamamlanana kadar ki tüm aşamalarında dâhil edildiği görülmüştür. Başlangıç aşamasında $(n=24)$, gereksinim aşamasında $(n=27)$, tasarım aşamasında $(n=27)$, geliştirme aşamasında $(n=18)$, test aşamasında $(n=21)$, sistemin açılması, kurulumu ve kullanımı gibi uygulama aşamasında $(n=10)$ ve müşteri destek aşamasında $(n=9)$ projeye dâhil edildiğini bildiren katıımcılar da bulunmaktadır (Şekil 8).

Şekil 8. Katıımcıların kurumlarında yürütülen projelere dâhil edilme aşamaları

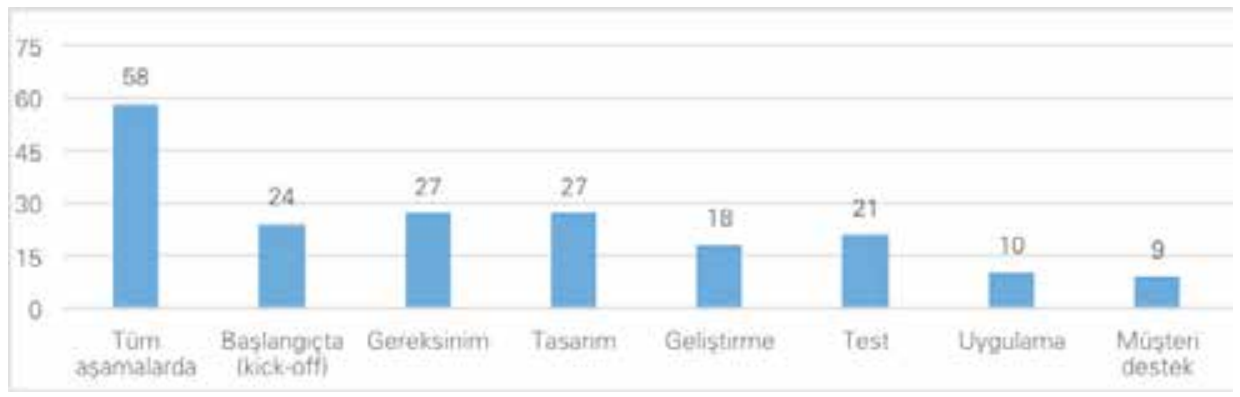

Çalışmada yer alan 19 katılımcı çalıştıkları son projelerde kullanıcı deneyimi aktivitelerinin geliştirme süreçlerine ileri seviyede entegre edildiğine yönelik cevap verirken, 11 katılımcı hiç entegre edilmediğini ifade etmiştir. Ayrıca, 23 katılımcı kötü seviyede entegre edildiğini, 19 katılımcı orta seviyede entegre edildiğini ve 19 katılımcı da iyi seviyede entegre edildiğini belirtmiştir.

Katılımcıların kullanıcı deneyimi profesyoneli olarak yaşadıkları zorluklara bakıldığında; kaynak yetersizliği (zaman, para ve malzeme gibi) ( $n=50)$, kurum, 
ekip veya proje içerisinde kullanıcı deneyimi konusunda bilgi eksikliği $(n=40)$, kullanıcı deneyimi konusunda yetkin personel eksikliği $(n=36)$ ve geliştiriciler ile iletişim sorunu ( $n=32)$ en fazla öne çıkan zorluklar olarak belirlenmiştir. Bunların dışında, kurumsal veya yönetimsel desteğin eksikliği $(n=29)$, kurum, ekip veya proje içerisinde uygun yöntemin olmaması $(n=27)$, kurum içerisinde kullanıcı deneyimine düşük öncelik verilmesi $(n=24)$, kullanıcılar hakkında bilgi eksikliği olması ( $n=19)$ ve geliştirilen yazılım, ürün veya sistem hakkında domain bilgisi eksikliği $(n=16)$ katılımcılar tarafından belirtilen diğer zorluklardandır (Şekil 9).

Şekil 9. Katılımcıların kullanıcı deneyimi profesyoneli olarak yaşadıkları zorluklar

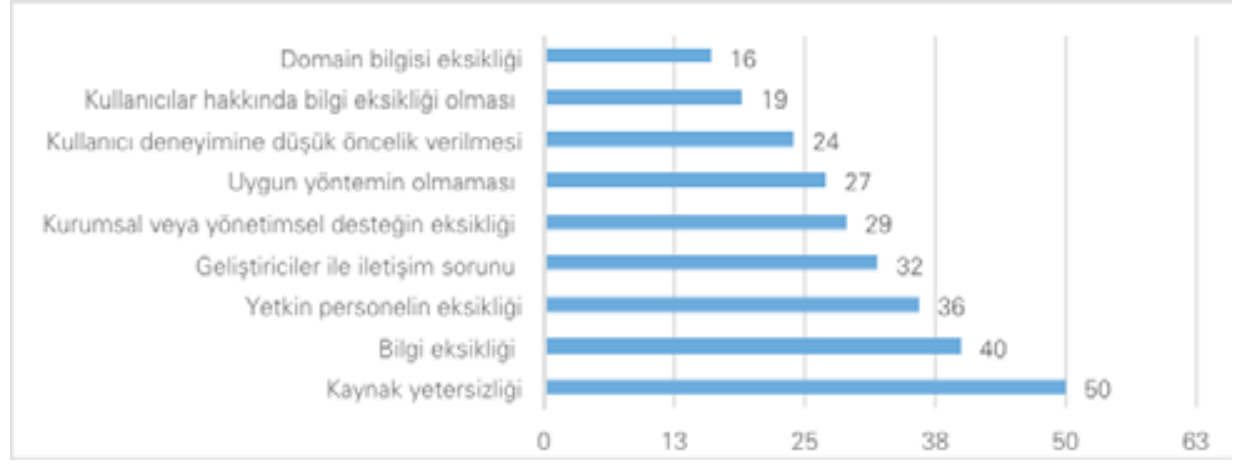

Kullanıcı deneyimi değerlendirmesi ve tasarım süreçlerinin verimliliğini arttırmak için değişiklik hakları olsa, katılımcıların önemli bir bölümünün üst yönetimden daha fazla destek $(n=40)$ talep edeceği görülmüştür. Ayrıca, proje ekibi arasında daha fazla işbirliği $(n=36)$, geliştiriciler ile daha iyi iletişim $(n=32)$ ve daha fazla kullanıcı deneyimi profesyoneli işe almak da yine talep edilen diğer konulardır. Bunları sırasıyla, kullanıcı deneyimi profesyonelleri için eğitim ve seminer $(n=29)$, daha iyi araçlar ve yöntemler adapte etmek $(n=28)$, araştırma ekibinden daha iyi veya daha uygun yöntemler önerilmesi $(n=27)$ ve kullanıcı araştırması için bütçeyi arttırmak $(n=26)$ takip etmektedir.

\section{Türkiye'deki Kullanıcı Deneyimi Topluluğu Profili}

Çalışmada yer alan katılımcıların ulusal veya uluslararası bir kullanıcı deneyimi topluluğuna üye olup olmadıkları, kendi gelişimlerinin takibi açısından önemli olmaktadır. Türkiye'de her ne kadar kullanıcı deneyimi profesyonellerini bir araya getiren ufak çaplı organizasyonlar bulunsa da, bu organizasyonlarda yer alan profesyonellerin sayısı oldukça azdır ve organizasyonlar alanda yeterince etkin olamamaktadır. Bu bağlamda kendilerine sorulan soruya verdikleri cevaba göre, katııımcıların büyük bölümü $(n=64)$ ulusal ölçekte bir kullanıcı deneyimi topluluğuna üye olmadığını belirtirken, az sayıdaki katıııcı $(n=25)$ Uluslararası Kullanıcı Deneyimi Profesyonelleri Birliği'nin (UXPA) Türkiye topluluğuna üye olduğunu belirtmiştir. Benzer şekilde katılımcıların neredeyse tamamına yakını 
( $n=76)$ uluslararası bir kullanıcı deneyimi topluluğuna üye olmadığını, sadece 11 katıımcı UXPA üyesi olduğunu ifade etmiştir.

\section{Tartışma}

Bu bölümde anketin farklı bölümlerinin sunduğu bulgular Türkiye'de kullanıcı deneyimi ekosisteminin oluşumu ve gelişimine sunduğu katkı bağlamında incelenmiştir.

\section{Demografik Profil bağlamında Kullanıcı Deneyimi Ekosistemi}

Lisans ve yüksek lisans ağılıklı eğitim almış olan profesyonellerin büyük bölümü Türkiye'de kullanıcı deneyimi odaklı bir eğitim mevcut olmadığı için farklı disiplinlerden gelmektedir. Çalışmada yer alan kullanıcı deneyimi profesyonellerinin dağılımında cinsiyet merkezli bir eşitsizlik gözlenmemiştir. Her iki cinsiyet grubundan da birbirine yakın sayıda profesyonelin ekosistem içerisinde çalıştığı söylenebilir. Medya ve iletişim, bilgisayar ve bilişim (enformatik), işletme ve yönetim ve etkileşim, medya ve iletişim tasarımı programları ağılıklı olarak öne çıkan programlardır. Literatürde yer alan benzer çalışmalarda kullanılabilirlik ve kullanıcı deneyimi uzmanlarının bilgisayar bilimleri, mühendislik, tasarım, bilişsel bilimler, görsel sanatlar, davranışsal bilimler, sosyal bilimler psikoloji ve insan faktörü gibi sadece teknik değil aynı zamanda teknik olmayan alanlardan da mezun oldukları belirlenmiştir (Gulliksen vd., 2004; Ji ve Yun, 2006; Zhou vd., 2008). Dolayısıyla, insan odaklı bir tasarım geliştirme süreci olan kullanıcı deneyimi tasarımı alanında dünyada olduğu gibi Türkiye'de de psikoloji, sosyoloji, dilbilim gibi sosyal bilimler alanından gelen uzmanların sayısının artmasının alana somut katkılar sunmak adına olumlu olacağı düşünülmektedir.

Çalışanların büyük bölümünün organizasyonel hiyerarşi içerisindeki pozisyonu proje yöneticisi, takım lideri vb. gibi orta/alt kademe yönetici pozisyonları veya konu alanı uzmanıdır. Bu tespit kullanıcı deneyimi profesyonellerinin özel bir uzmanlık alanı olarak karar verici seviyelerinde konumlandıııdığını göstermesi açııından önemlidir. Buna karşın Boivie vd. (2006) tarafından yapılan çalışmada bilişim teknolojileri çalışanı veya kullanılabilirlik tasarımcısı gibi konu alan uzmanı pozisyonunda çalıştıkları belirlenmiştir. Chilana vd. (2011) ve Gulliksen vd. (2004) ise çalışmalarında kullanıcı deneyimi yöneticisi veya proje yöneticisi pozisyonunda oldukça az sayıda profesyonelin çalıştığını, ancak büyük çoğunluğun konu alan uzmanı olarak görev aldığını belirlemiştir.

Unvanlar açısından değerlendirildiğinde ağırlıklı olarak kullanıcı deneyimi ile başlayan bir unvan çeşitliliğinin var olduğu görülmüştür. Kullanılabilirlik merkezli unvanların sayısının azlığı, sektörde ilgili kavramın yerini kullanıcı deneyimine bıraktığı doğrultusunda yorumlanmıştır. Ancak bu noktada kullanıcı deneyimi ve etrafında gelişen ilgili kavramların bir tür popüler eğilim olarak sahiplenilmesinin de söz konusu durum üzerinde etkili olduğu düşünülmektedir. Literatürde yer 
alan benzer çalışmalar incelendiğinde de bu değişim görülmektedir. Örneğin 2000 'li yılların başlarında yapılan benzer çalışmalarda (Gulliksen vd., 2004; Boivie vd., 2006) kullanılabilirlik ile ilgili unvanların kullanıldığı, buna karşın son yıllarda yapılan çalışmalarda (Chilana vd., 2011) kullanıcı deneyimi ağırlıkı unvanların popülerlik kazandığı görülmektedir. Kullanılabilirlik ve kullanıcı deneyimi ekosistemi son yıllarda gelişmeye başlayan ve çalışanlarının genç yaşlarda insanlar olduğu bir uzmanlık alanı olmaktadır. Bu bağlamda önceki çalışmalarla benzer şekilde (Vredenburg vd., 2002; Gulliksen vd., 2004; Ji ve Yun, 2006; Chilana vd., 2011), bu çalışmada da kullanıcı deneyimi profesyonellerini gerek toplam iş tecrübesi ve gerekse de kullanıcı deneyimi alanındaki iş tecrübelerinin çok fazla olmadığı görülmektedir. Örneğin, katılımcıların ortalama iş deneyimi 9 yıl olmakla birlikte kullanıcı deneyimi alanındaki deneyimlerinin ortalama 4 yıl olması, kullanıcı deneyimi ekosisteminin son 4-5 yılda oluştuğunu göstermesi açısından önemlidir. Nitekim farklı bölümlerde sorulan "kurumun kullanıcı deneyimiyle ilgili deneyiminin kaç yıla yayıldığı" gibi ilişkili sorulara verilen cevaplar da bu tespiti destekler niteliktedir.

\section{Kurumsal Yapı bağlamında Kullanıcı Deneyimi Ekosistemi}

Kullanıcı deneyimi ekosisteminin merkezi İstanbul olarak dikkat çekmektedir. Ekosistem içindeki dağılım hangi sektörlerin öncü olarak alana yatırım yaptığını göstermesi açısından önemlidir. Literatürde yer alan araştırmalar (Gulliksen vd., 2004; Ji ve Yun, 2006; Zhou vd., 2008) bilgisayar, internet, e-ticaret, finans, araştırma ve eğitim, sağlık ve telekomünikasyon sektörlerinde uzmanların daha fazla yoğunlaştıklarını ortaya koymaktadır. Benzer şekilde bu çalışmada da çevrimiçi habercilik, e-ticaret gibi girişimleri barındıran bilgi ve iletişim sektörü, üniversite araştırmacılarını barındıran eğitim sektörü ve şubesiz bankacılık kanalı üzerinden sektörün itici gücünü oluşturan finans sektörü bu başlıkta öne çıkmaktadır.

Bu çalışmada elde edilen bulgulara benzer şekilde Gulliksen vd. (2004) ve Chilana vd. (2011) kullanıcı deneyimi profesyonellerinin çoğunlukla büyük ölçekli organizasyonlarda daha fazla istihdam edildiğini ortaya koymuşlardır. Bu çalışmada aynı zamanda küçük ölçekli kurumların kullanıcı deneyimine yönelik ilgisinin orta ölçekli kurumlara kıyasla daha fazla olduğu görülmüştür. Bu sonuç Gulliksen vd. (2004) tarafından kullanılabilirlik ve Chilana vd. (2011) tarafından kullanıcı deneyimi profesyonellerinin meslek içi uygulamalarını araştıran çalışmalardaki en fazla istihdam edilen organizasyonların sırasıyla, büyük, küçük ve orta ölçekli kurumlar olduğu sonucu ile örtüşmektedir. Bu noktada küçük ölçekteki genç girişimcilerin etkili olduğu düşünülmektedir. Nitekim kurum içinde yaygın olarak kullanılan yöntemler içinde öne çıkan "çevik/yalın" ve "hızlı prototiplendirme" yaklaşımlarının dünyada özellikle genç girişimciler tarafından ortaya atılması ve yaygın olarak kullanılması bu durumu teyit eder niteliktedir. Sayıca oldukça fazla olan orta ölçekli kurumların konuya yönelik ilgisini arttırmak üzere özel çalışmalar yapılması gerektiği düşünülmektedir. 
Kurumların ulusal/uluslararası ölçekte dağıımının yarı yarıya olduğu görülmektedir. Yurtdışında daha olgun bir seviyede benimsenmiş olan kullanıcı deneyimi yaklaşımının uluslararası şirketlerle Türkiye ekosistemine taşındığı söylenebilir. Ancak bu noktada ulusal kurumların da sürece kendini adapte etme konusunda istekli olduğu ortadadır. Ağırlıkla özel sektörün başı çektiği bu alanda kamunun varlığının oldukça sınırlı olması düşündürücüdür. On beş bin aktif alan adına sahip olan ve e-Devlet Kapısı, Merkezi Hekim Randevu Sistemi (MHRS) gibi kritik hizmetleri dijital platformlara taşıma iddiasındaki kamu kurumlarının alana yönelik ilgisinin bu denli zayıf olması üzücüdür. Bu durumu değiştirmek ve kamu nezdinde ilgili farkındalığı arttırıp pro-aktif süreçleri tetikleyecek stratejileri geliştirmek gerekmektedir.

Kurumların kullanıcı deneyimi profesyonellerine yaptıkları yatııma ve istihdam politikalarına bakıldığında, organizasyonlardaki çalışan sayısının ağırlıklı olarak 0-5 arasında yer alması henüz küçük ekiplerin istihdam edildiğini göstermektedir. Nitekim konuya yapılan yatıımın maksimum 5 yıllık bir geçmişi olması da bu alana yönelik ilginin nispeten yeni ve gelişime açık olduğu şeklinde yorumlanmıştır. Benzer şekilde Ji ve Yun (2006) tarafından yapılan çalışmada da kullanılabilirlik takımlarının önemli oranda bir kişiden ve çoğunlukla da iki-üç kişilik ekiplerden oluştuğu belirlenmiştir.

\section{Kullanıcı Deneyimi Konusunda Temel Bilgi ve Farkındalık Seviyeleri bağlamında Kullanıcı Deneyimi Ekosistemi}

Kullanıcı deneyimi profesyonellerinin kullanıcı deneyimi konusunda yaygın ve popüler tanımları bildiği görülmüştür. Ancak bu tanımlar ötesinde daha detaylı bir kavramsallaştırma yapma isteği gözlenmemiştir. Yine kendilerine alanda ağırlıkı olarak kullanılan teori ve yöntemler sorulduğunda bu bağlamdaki bilgilerinin sınırlı olduğu belirlenmiştir. Farklı teori ve yöntemleri bildiğini ifade edenler sadece akademisyenlerdir. Nitekim katıımcıların kullanıcı deneyimi alanına yönelik kendi bilgi seviyelerini değerlendirmeleri istendiğinde kendilerine bu bağlamda güvenmedikleri ve bilgi seviyelerini ağılıklı olarak orta seviye olarak belirttikleri görülmüştür. Buna karşın önceki çalışmalar, kullanılabilirlik ve kullanıcı deneyimi profesyonellerinin farklı teori ve yöntemler konusunda bilgi sahibi olduklarını ortaya koymaktadır. Örneğin, Gulliksen vd. (2004) kullanılabilirlik uzmanlarının sesli düşünme yöntemi, mülakat, saha çalışması ve düşük-sadakatli prototiplendirme aktivitelerinde daha fazla bilgi sahibi olduklarını belirtirken, Zhou vd. (2008) arayüz/ etkileşim tasarımı, görsel tasarım, gereksinim analizi, kullanılabilirlik testi, görev analizi, memnuniyet anketi ve kullanıcı araştırmasının sıklıkla kullanılan yöntemler olduğunu belirtmiştir. Hussein vd. (2012) ise şelale yöntemi, görev analizi, kullanıcı kabul testleri, kullanıcı deneyimi, mevcut sistemlerin değerlendirilmesi, anket ve sezgisel değerlendirmelerin sıklıkla kullanılan teknikler olduğunu belirlemişlerdir.

Clemmensen (2003) tarafından yapılan araştırmada, özellikle insan bilgisayar etkileşimi alanında alınan eğitimler ile kullanılabilirlik uzmanlarının daha 
fazla farkındalık sahibi oldukları ve bu eğitimlerin kullandıkları teori ve yöntemleri etkilediği, eğitim alan uzmanların teori ve yöntemlere yönelik daha fazla bilgi sahibi olduklarını ortaya koymaktadır. Uluslararası ölçekte, özellikle insan bilgisayar etkileşimi, kullanılabilirlik, insan faktörü ve kullanıcı deneyimi konularında lisans veya lisansüstü programlarında bu alanlara yönelik dersleri son yıllarda yoğun olarak görmek mümkündür. Örneğin, Hussein vd. (2012) tarafından yapılan bir araştırmada, Malezya ölçeğinde, katılımcıların önemli bölümünün bu konularda örgün eğitim aldıkları belirtilmektedir.

Ancak bu çalışmada yer alan katılımcıların önemli bir bölümünün kullanılabilirlik ya da kullanıcı deneyimi merkezli herhangi bir örgün eğitim almamış olmalarının bilgi ve farkındalık seviyelerinde etkili olduğu görülmüştür. Bu konularda eğitim aldığını ifade edenlerin eğitim kurumlarındaki konuyla teması lisans veya lisansüstü seviyede aldıkları derslerle sınırlıdır. Lisans veya lisansüstü programlarda konuyla ilgili derslerin sayısının arttırıması ve uzun vadede bu konu odakı lisansüstü programların açılmasının sağlanması hedeflenmelidir. İlgili eğitim programı ve derslerin açılmasının ancak yeterli eğitmenin yetiştirilmesiyle mümkün olacağı da unutulmamalıdır. Bu bağlamda alanda çalışacak araştırmacı ve eğitmenlerin yetiştirilmesine yönelik süreçlerin hem kamu hem de özel sektör nezdinde harekete geçirilmesi gerekmektedir.

Kullanıcı deneyimi profesyonellerinin örgün eğitim dışında farklı kanallardan yaşam boyu eğitim desteği alma konusunda da özel bir çaba göstermedikleri görülmüştür. Katılımcıların kullanıcı deneyimi alanındaki gelişmelere yönelik ilgileri blog, haber siteleri ve dergiler ile sınırlıdır. Alandaki diğer profesyonellerle buluşmaya yönelik girişimleri de sınırlı ölçüdedir. Katılımcıların önemli bir bölümü son 12 ay içerisinde kullanıcı deneyimi alanıyla ilgili ulusal veya uluslararası herhangi bir etkinliğe katılma olanağı bulamamıştır. Bu durum, Türkiye'de çalışan kullanıcı deneyimi profesyonellerinin hem kendilerini teorik olarak geliştirmelerinin hem de uluslararası kullanıcı deneyimi toplulukları ile etkileşimlerinin önünde bir engel teşkil etmektedir. Alana yatıım yapan kurumların çalışanlarını söz konusu etkinliklere göndermek üzere fonlar oluşturması bu açıdan çok kritiktir.

\section{Kullanılan Yöntem ve Araçlar bağlamında Kullanıcı Deneyimi Ekosistemi}

Gulliksen vd. (2004) kullanılabilirlik uzmanlarının kullanıcılarla daha fazla iletişimde olmak istediklerini ve görev aldıkları projelerde kullanıcılarla iletişimde bulunmadıkları durumda mutsuz olduklarını belirlemişlerdir. Bu çalışmada yer alan katıımcıların büyük bölümünün de görev aldıkları projelerde kullanıcılarla yüz yüze iletişime geçtiği ve genel olarak kullanılabilirlik testi yaptığı belirlenmiştir. Nitekim katılımcıların geçen yıl içerisinde kullanıcı deneyimi konusunda gerçekleştirdikleri aktivitelere bakıldığında, en çok kullanıcı araştırması yapıldığı görülmüştür. Bu durum, kullanıcı araştırmalarının Türkiye'de yüksek oranda benimsendiğini göstermesi açısından önemli bir bulgudur. Her ne kadar kullanılabilirlik testi 
yöntemi ağırlıklı olarak yüz yüze sürdürülmekte olup uzaktan test teknolojileri gibi alternatif yaklaşımlar henüz yeterince yaygınlaşmasa da, $A / B$ testi, gerilla kullanılabilirlik testi, ağaç testi gibi farklı değerlendirme yöntem ve araçlarının kullanıldı̆ını görmek olumlu bir bulgu olarak değerlendirilmiştir.

Kullanıcı deneyimi tasarımı açısından mevcut durumun test yöntemlerinin benimsenme oranına kıyasla daha iyi olduğu belirlenmiştir. Özellikle hem düşük hem de yüksek sadakatli prototiplendirme süreçlerine yönelik ilgi dikkat çekicidir. Ancak bu noktada öne çıkan temel bulgu söz konusu süreçlerde ağırlıklı olarak kâğıt/kalem ve Adobe Photoshop araçlarının kullanıldığıdır. Bu durum, ekosistemin büyük bölümünü oluşturan büyük ölçekli firmaların dahi kullanıcı deneyimi tasarımı araçlarına beklenen seviyede yatıım yapmadığı doğrultusunda yorumlanmıştır. Prototip araçlarına yatıım yapmayan kurumlar, çalışanlarına eldeki mevcut araçların kullanımını dayatmaktadır. Bu anlamda ilgili araç ve ekipmana yatırım yapacak kaynakların hazırlanması elzem gözükmektedir.

\section{Kullanıcı Deneyimi Çalışmalarının Kurumların Organizasyonu ve iş Yapış Biçimlerine Entegrasyonu bağlamında Kullanıcı Deneyimi Ekosistemi}

Katılımcıların çalıştıkları organizasyonlardaki farklı unvan ve sorumluluklarda çalışanların kullanıcı deneyimini hangi seviyede bildikleri kendilerine sorulduğunda, özellikle üst yönetim, proje yönetimi ve geliştiricilerin kullanıcı deneyimi konusunda bilgi sahibi olduklarını, buna karşın proje içerisinde yer alan müşteri destek ve pazarlama gibi destek bölümlerinde çalışanların bu konuda bilgi sahibi olmadıklarını ifade etmişlerdir. Farklı birimlerin desteğinin minimumda olması literatürdeki bulgularla örtüşmektedir. Kurum içi iletişimin bu doğrultuda geliştirilmesi için çaba sarf edilmelidir.

Çalışmada yer alan katıımcıların önemli bölümünün çalıştıkları kurumlarda yürütülen projelerin tüm aşamalarında aktif olarak görev aldıklarını bildirmeleri önemlidir. Ancak literatürdeki çalışmalarla da benzer şekilde (Boivie vd., 2006; Chilana vd., 2011), sadece tüm süreçlerde değil, proje sürecinin sadece belli aşamalarında kullanıcı araştırması ve prototiplendirme gibi bazı aktiviteler kapsamında projeye dahil olduklarını söyleyen katılımcılar da bulunmaktadır.

Önceki çalışmalar kullanılabilirlik ve kullanıcı deneyimi profesyonellerinin özellikle üst yönetim desteğini önemli gördükleri ve bu konuda sıkıntı yaşamak istemediklerini ortaya koymaktadır (Boivie vd., 2006). Gulliksen vd. (2004) kullanılabilirliğin proje planında en başından beri yer alması, proje yönetiminden destek, üst yönetimden destek, kullanıcılardan destek ve yazılım geliştiricilerden kabul görmelerini kullanılabilirliğin çalışma ortamlarında etkin şekilde adapte edilmesi için gerekli duyulan önemli faktörlerden olduğunu belirtmişlerdir. Başka bir çalışmada (Ji ve Yun, 2006) ise kullanılabilirliğe yönelik bilgi eksikliği, uygun yöntemin belirlenmesindeki eksiklik, geliştirme maliyetlerine ve zamana yönelik çekinceler ve kullanılabilirlik uzmanlarının gerekli eğitimleri alamaması bu konudaki 
zorluklar olarak belirlenmiştir. Ayrıca, Hussein vd. (2012) geliştirme süreçlerinin uzayacağına yönelik endişe, kullanılabilirlik/kullanıcı deneyimi konularında bilgi eksikliği, geliştirme süreçlerine gerçek kullanıcıların dâhil edilmesinde sıkıntılar ve profesyonellerin yeterli eğitimi alamamalarını karşılaşılan temel zorluklar olarak ortaya koymaktadır.

Bu çalışmada da üst yönetimin konuya yönelik bilgisi olsa da süreçlere daha çok dâhil olmaları temel bir talep olarak dikkat çekmektedir. Kurumlarda kullanıcı merkezli dönüşümün yukarıdan aşağıya doğru gerçekleşmesi daha kolay ve etkili olabilmektedir. Nitekim kullanıcı deneyiminin değerlendirilmesi ve tasarım süreçlerinin verimliliğini arttırmak için değişiklik hakları olsa, katılımcıların önemli bir bölümünün üst yönetimden daha fazla destek talep edeceği görülmüştür. Proje ekibi arasında daha verimli bir iletişimin sağlanması talebi de yukarıdaki tespiti destekler niteliktedir. Bu taleplerin dışında kalan diğer talepler yeni ekip üyeleri, yeni araçlar ve sürekli eğitim için zaman ve bütçe kaynakları yaratmak etrafında odaklanmaktadır. Tek kişilik dev kadrolar halinde çalışmak zorunda kalan profesyonellerin yeni yetkin ekip üyeleriyle desteklenmesi önemlidir. Eğitime yönelik talep daha önceki bölümlerde vurgulanan bilgi ve farkındalığa yönelik eksikliğin kişisel olarak da tespiti açısında önemlidir. Alan içinde yaşam boyu eğitime olanak sağlayacak kaynakların çalışanlar için sunulması gerekmektedir.

Bu talepler katılımcıların kullanıcı deneyimi profesyoneli olarak yaşadıkları zorluklarla örtüşmektedir. Literatürde yer alan önceki çalışmalarla (Dillon vd., 1993; Bekker ve Vermeeren, 1996; Boivie vd., 2006) da benzerlik gösterecek şekilde en çok dile getirilen sorunlar: Zaman, para ve malzeme gibi kaynak yetersizliği, kurum, ekip veya proje içerisinde kullanıcı deneyimi konusunda bilgi eksikliği, kullanıcı deneyimi konusunda yetkin personelin eksikliği ve geliştiriciler ile iletişim sorunudur. Kullanıcı deneyimi profesyonelleri dijital ürün geliştirme sürecinin tüm fazlarına doğrudan eşlik etmeye başlamışlardır ancak bunun sürekli hale getirilmesi önemlidir. Bu anlamda konuya yukarıdan aşağıya bir hiyerarşi içinde tüm kaynakları seferber ederek yatırım yapmak konunun kurum kültürünün bir parçası olarak benimsenebilmesi açısından kritiktir.

\section{Türkiye'deki Kullanıcı Deneyimi Topluluğunun Profili bağlamında Kullanıcı Deneyimi Ekosistemi}

Çalışmada yer alan katıımcıların ulusal veya uluslararası bir kullanıcı deneyimi topluluğuna üye olup olmadıkları, kendi gelişimlerinin takibi açısından önemli olmakla birlikte katılımcıların neredeyse tamamına yakını uluslararası bir kullanıcı deneyimi topluluğuna üye olmadığını belirtmiştir. Bir ekosistemin tüm bileşenleriyle gelişimi ancak üyelerinin birbirleriyle düzenli etkileşimi sayesinde mümkün olabilmektedir. Bu etkileşimi mümkün kılacak örgütlerin kurulması ve çeşitlilik arz eden düzenli faaliyetlerle üyelerini çatısı altında dayanışma merkezli olarak buluşturması gerekmektedir. 


\section{Sonuç}

Bu çalışmanın amacı Türkiye'deki kullanıcı deneyimi profesyonellerinin profillerini, çalışma ortamlarını, çalışma sürecinde kullandıkları yöntemleri ve mevcut iş akışı içindeki konumlarını inceleyerek kullanıcı deneyimi ekosistemine yönelik kapsamlı bir analiz ortaya koymaktır. Elde edilen bulgular söz konusu ekosistem hakkında detaylı bir resim ortaya konmasına olanak sağlamıştır.

Mevcut yapının gelişerek büyümesi için aşağıdaki tespitler ve somut öneriler sunulmuştur:

- Kullanıcı deneyimi ekosisteminin özel sektörde faaliyet gösteren büyük ölçekli firma ağırlıklı ve istanbul merkezli olduğu görülmektedir. Kullanıcı deneyimi kavramının sadece bilişim dünyasında değil, ürün ve hizmet sektöründe de aktif olarak kullanıldığı düşünüldüğünde, mevcut ekosistemin ulusal ölçekte farklı iş kollarında genişletilmesine intiyaç bulunmaktadır.

- Kullanıcı deneyimi alanında çalışanların büyük bölümünün organizasyonel hiyerarşi içerisindeki pozisyonu proje yöneticisi, takım lideri vb. gibi orta/alt kademe yönetici pozisyonları veya konu alanı uzmanıdır. Kullanıcı deneyimi mesleğinin özel bir uzmanlık alanı olarak dikkate alındığı ve karar verici seviyelerinde konumlandıııdığı tespit edilmiştir.

- Küçük ölçekli firmaların kullanıcı deneyimine ilgisi orta ölçekli firmalardan daha fazla olurken, kamu kurumlarının bu alanda oldukça sınırlı varlık gösterdiği belirlenmiştir. Kullanıc deneyimi ekosisteminin gelişmesi açısından, farklı ölçeklerdeki kurumlarda bilgi ve farkındalığın arttırılması önemlidir. Kamu özelinde ilgili farkındalığı arttııр kamunun bizzat inisiyatif alacağı etkin süreçleri başlatacak stratejileri geliştirmek gerekmektedir.

- Kurumlarda ilgili ekiplerde çalışan sayısının ağırııkı olarak 0-5 arasında yer alması henüz bu kapsamda küçük ekiplerin istihdam edildiğini göstermektedir. Nitekim konuya yapılan yatırımın maksimum 5 yıllık bir geçmişi olması da konuya yönelik ilginin nispeten yeni ve gelişime açık olduğu şeklinde yorumlanmıştır.

- Kullanıc deneyimi profesyonellerinin kullanıcı deneyimi konusunda yaygın ve popüler tanımları bildiği ancak kendi bilgi seviyelerini yeterli düzeyde görmediği ve büyük oranda bu konularda herhangi bir örgün eğitim almadıkları tespit edilmiştir. Bu bağlamda, lisans veya lisansüstü programlarda konuyla ilgili derslerin sayısının arttırılması ve uzun vadede bu konu odaklı akademik programların açımasının sağlanması hedeflenmelidir.

- Hem yaşam boyu eğitime olanak sağlayacak hem de uluslararası kullanıcı deneyimi toplulukları ile etkileşimi mümkün kılacak kaynakların çalışanlar için sunulması gerekmektedir. 
- Kullanıcı araştırmalarının Türkiye'de yüksek oranda benimsendiği görülmüştür. Ancak büyük ölçekli firmaların dahi ekipleri için kullanıcı deneyimi tasarım araçlarına beklenen seviyede yatıım yapmadığı tespit edilmiştir. Bu anlamda ilgili araç ve ekipmana yatırım yapmak üzere gerekli kaynakların hazırlanması gerekmektedir.

- Kullanıcı deneyimi profesyonelleri dijital ürün geliştirme sürecinin tüm ayaklarına eşlik etmeye başlamışlardır. Ancak bunun kurum kültürünün bir parçası haline getirilmesi önemlidir. Bu anlamda konuya yönetim kademelerinde destek vererek kurum içinde yukarıdan aşağıya bir hiyerarşi içinde sahip çıkmak önemlidir.

- Kullanıcı deneyimi profesyonellerinin gelişimlerini iyileştirmek için özellikle kurum içerisindeki iletişim kanallarını ve kaynaklarını zenginleştirmeyi istedikleri tespit edilmiştir.

- Gerek ulusal ve gerekse de uluslararası etkinliklere oldukça az katılım sağlayabildikleri, ulusal ve uluslararası kullanıc deneyimi toplulukları ile etkin bir iletişim ve etkileşimlerinin olmadığı görülmüştür.

- Yazılım, pazarlama gibi farklı birimlerin desteğiyle kurum içi iletişimin bu doğrultuda geliştirilmesi, sınırlı kadrolarla çalışmak zorunda kalan profesyonellerin yeni ekip üyeleriyle desteklenmesi bu açıdan önem taşımaktadır.

- Bir ekosistemin tüm bileşenleriyle gelişimi ancak üyelerinin iş ortamı dışında birbirleriyle düzenli etkileşimi sayesinde mümkün olabilmektedir. Bu etkileşimi mümkün kılacak örgütlerin kurulması ve çeşitlilik arz eden düzenli faaliyetlerle üyelerini çatısı altında dayanışma merkezli olarak buluşturması gerekmektedir.

Çalışmada ortaya konulan bulguların, Türkiye'deki kullanıcı deneyimi ekosisteminin mevcut durumunun ortaya konulmasında yol gösterici olması hedeflenmektedir. Türkiye'de henüz gelişme aşamasında olan ekosistemde yer alan sorunların giderilmesi ile kullanıcı deneyimi profesyonellerinin sadece ulusal değil, aynı zamanda uluslararası düzeyde de çalışabilecek yetkinlikte bireyler olması sağlanabilecektir. Bunun yanında, uluslararası bir araştırma projesinin Türkiye ayağında toplanan verileri kapsayan bu çalışma sonuçlarının, araştırma projesi kapsamında Danimarka, Finlandiya, Malezya ve Fransa'da çalışan kullanıcı deneyimi profesyonellerinden toplanan veriler ile kültürler arası bir yaklaşımla karşılaştırmalı olarak ele alınması da planlanmaktadır. 


\section{Kaynakça}

Anderson, J., Fleek, F., Garrity, K., \& Drake, F. (2001). Integrating usability techniques into software development. IEEE Software, January/February, 4653.

Ardito, C., Buono, P., Caivano, D., Costabile, M.F., Lanzilotti, R., Bruun, A., ve Stage, J. (2011). Usability evaluation: A survey of software development organizations. International Conference on Software Engineering and Knowledge Engineering, 282-287, Miami, FL, USA.

Bekker, M.M. ve Vermeeren, A.P.O.S. (1996). An analysis of user interface design projects: information sources and constraints in design. Interacting with Computers, 8(1), 112-116.

Boivie, I., Gulliksen, J., ve Göransson, B. (2006). The lonesome cowboy: A study of the usability designer role in systems development. Interacting with Computers, 18, 601-634.

Borgholm, T. ve Madsen K.H. (1999). Cooperative usability practices. Communications of the ACM, 42(5), 91-97.

Bygstad, B., Ginea, G., \& Brevik, E. (2008). Software development methods and usability: Perspectives from a survey in the software industry in Norway. Interacting with Computers, 20, 375-385.

Catarci, T., Matarazzo, G., ve Raiss, G. (2002). Driving usability into the public administration: The Italian experience. International Journal of Human-Computer Studies, 57, 121-138.

Chilana, P.K., Ko, A.J., Wobbrock, J.O., Grossman, T., ve Fitzmaurice, G. (2011). Post-deployment usability: A survey of current practices. CHI 2011, 2243-2246, Vancouver, BC, Canada.

Clemmensen, T. (2003). Usability professionals' personal interest in basic $\mathrm{HCl}$ theory. INTERACT 2003, 639-646, Zurich, Switzerland.

Clemmensen, T. (2005). Community knowledge in an emerging online professional community: The case of Sigchi.dk. Knowledge and Process Management, 12(1), 43-52.

Coşkan, D. ve Onay Durdu, P. (2014). Kullanılabilirlik ve yazııım yaşam döngüsü: Türkiye'deki yazııım organizasyonlarındaki durum. 8. Ulusal Yazılım Mühendisliği Sempozyumu, 55-66, Güzelyurt, KKTC.

Dillon, A., Sweeney, M., ve Maguire, M. (1993) A survey of usability evaluation practices and requirements in the European IT industry. In. J. Alty, S. Guest and D. Diaper (eds.) HCl'93. People and Computers VII. Cambridge: Cambridge University Press. 
Gulliksen, J., Boivie, I., Persson, J., Hektor, A., ve Herulf, L. (2004). Making a difference - a survey of the usability profession in Sweden. NordiCHI 2004, 207215, Tampere, Finland.

Hussein, I., Mahmud, M., ve Md Tap, A.O. (2012). User experience design (UXD): A survey of user interface development practices in Malaysia. Southeast Asian Network of Ergonomics Societies Conference, Langkawi, Malaysia.

Hussein, I., Mahmud, M., Md Tap, A.O., ve Jack, L. (2013). Does user-centered design (UCD) matter? Perspectives of Malaysian IT organizations. International Journal of Interactive Digital Media, 1(1), 71-78.

International Organization for Standardization (2009). Ergonomics of human system interaction - Part 210: Human-centered design for interactive systems (formerly known as 13407). ISO F \pm DIS 9241-210:2009.

Inal, Y. ve Guner, H. (2016). Yazılım geliştiricilerin kullanıcı deneyimi ve kullanılabilirlik konusundaki farkındalıklarının ve bilgi seviyelerinin belirlenmesi. Pamukkale Üniversitesi Mühendislik Bilimleri Dergisi, 22(5), 384-389.

Jerome, B. ve Kazman R. (2005). Surveying the Solitudes. An Investigation into the relationships between Human Computer Interaction and Software Engineering in Practice, In: Human-Centered Software Engineering - Integrating Usability in the Software Development Lifecycle, Ahmed Seffah, Jan Gulliksen and Michel C. Desmarais, 59-70, Springer Netherlands, 978-1-4020-4027-6, Dordrecht, Netherlands.

Ji, Y.G. \& Yun, M.H. (2006). Enhancing the minority discipline in the IT industry: A survey of usability and user-centered design practice. International Journal of Human-Computer Interaction, 20(2), 117-134.

Juristo, N., Moreno, A.M., \& Sanchez-Segura M. I. (2007). Analysing the impact of usability on software design. Journal of Systems and Software, 80(9), 15061516.

Law, E.L.C., Roto, V., Hassenzahl, M., Vermeeren, A.P.O.S., ve Kort, J. (2009). Understanding, scoping and defining user eXperience: A survey approach. $\mathrm{CHI}$ 2009, 719-728, Boston, MA, USA.

Poltrock, S.E. ve Grudin, J. (1994). Organizational obstacles to interface design and development: Two participant - observer studies. ACM Transactions on Computer-Human Interaction, 1(1), 52-80.

Roche, A., Lespinet-Najib, V., ve Andre, J.M. (2014). Use of usability evaluation methods in France: The reality in professional practices. 3rd International Conference on User Science and Engineering, 180-185, Shah Alam, Malaysia.

Smith, A., Joshi, A., Liu, Z., Bannon, L, Gulliksen, J., ve Li, C. (2007). Institutionalizing $\mathrm{HCl}$ in Asia. INTERACT 2007, 85-99, Rio de Janeiro, Brazil. 
Vredenburg, K., Mao, J.Y., Smith, P.W., ve Carey, T. (2002). A survey of usercentered design practice. CHI 2002, 471-478, Minneapolis, Minnesota, USA.

Vukelja, L., Müller, L. ve Opwis, K. (2007). Are engineers condemned to design? A survey on software engineering and UI design in Switzerland. INTERACT 2007, 555-568, Rio de Janeiro, Brazil.

Xenos, M. (2001). Usability perspective in software quality. 8th Panhellenic Conference on Informatics with International Participation, 2, 523-529.

Zhou, R., Huang, S., Qin, X., \& Huang, J. (2008). A survey of user-centered design practice in China. In Proceedings from IEEE International Conference on Systems, Man and Cybernetics, 2008 (1885-1889). Singapore: IEEE Press. 